\title{
ALLERGIC BRONCHOPULMONARY ASPERGILLOSIS
}

\author{
Rashmi D'Mello', Sasikumar Kilaikode ${ }^{2}$, Sami L. Bahna $^{1}$ \\ ${ }^{1}$ Allergy and Immunology Section, Louisiana State University Health Sciences Center, \\ Shreveport, Louisiana, U.S.A. \\ ${ }^{2}$ Pediatric Pulmonary Section, Louisiana State University Health Sciences Center, \\ Shreveport, Louisiana, U.S.A.
}

\begin{abstract}
Aspergillus is a saprophytic mold and its natural habitat is the soil. It is found worldwide indoors and outdoors in potted soil, compost, freshly cut grasses, decaying vegetation and in sewers. Aspergillus produces a bountiful number of spores and releases $2-3$ micron sized spores into the air daily. It grows best at $37-40^{\circ} \mathrm{C}$, which is similar to the temperature in the lungs. These spores will remain airborne for a long period of time. It is estimated that humans inhale hundreds of spores daily. Several fungi other than aspergillus have been known to be implicated. Hence, the term allergic bronchopulmonary mycoses would be more appropriate unless the specific fungus is identified - which could be candida, helminthosporium, curvularia, bipolaris, cladosporium, or others. The review article is focused on the prototype allergic bronchopulmonary aspergillosis, its epidemiology, pathogenesis, diagnosis and treatment. Bronchopulmonary aspergillosis should be considered in patients with poorly controlled asthma despite appropriate routine therapy and environmental control. The need for frequent courses of corticosteroids with temporary improvement should raise the index of suspicion and appropriate evaluation be done. Early recognition and prompt initiation of appropriate corticosteroid treatment regimen would reduce the risk of development or progression of bronchiectasis and lung tissue damage. Regular follow up and monitoring serum total IgE level can predict exacerbations and should prompt corticosteroid treatment. Long term follow-up is important as relapses can occur years of remission.
\end{abstract}

Key words: Allergic bronchopulmonary aspergillosis, allergic pulmonary mycosis, uncontrolled asthma, asthma, cystic fibrosis, bronchiectasis, aspergillus

Corresponding author: Sami L. Bahna, MD, DrPH, Chief of Allergy \& Immunology Section Louisiana State University Health Sciences Center, 1501 Kings Highway, Shreveport, Louisiana 71130-3239, USA E-mail: SBahna@LSUHSC.edu

Для цитирования: Рашми д'Мелло, Сасикумар Килайкод, Сами Л. Бахна. Аллергический бронхолегочный аспергиллез // Вестник Российского университета дружбы народов. Серия: Медицина. 2019. T. 23. No 1. С. 62 - 69. DOI: 10.22363/23130245-2019-23-1-62-69.

For citation: Rashmi D’Mello, Sasikumar Kilaikode, Sami L. Bahna (2019). Allergic Bronchopulmonary Aspergillosis. RUDN Journal of Medicine, 23 (1), 62 -69. DOI: 10.22363/2313-0245-2019-23-1-62-69.

\section{INTRODUCTION}

Micheli first described the mold aspergillus in 1729 as it looks like aspergillum, the Latin term for a device used to sprinkle Holy water [1]. Bennett was the first physician to describe pulmonary asper- gillosis as "numerous jointed transparent tubes, here matted together, there isolated... mingled with round or oval corpuscles, which, however, were larger and more developed" [2]. Later, Fresenius described Aspergillus fumigatus as having "green pigmentation 
with no fertile septate hyphae or conidiophores". The word fumigatus means smoky in Latin, referring to the fungus' smoky blue-gray color. An association with human disease was first described in 1847 of a woman dying with an unspecified lung infection [3]. Virchow described four cases of pulmonary aspergillosis in patients dying of other conditions in 1856. In 1887, Osler reported the case of a young woman who coughed up sputum for eleven years of mycelia and spores of aspergillus. In 1897, Renon was the first to associate aspergillus with asthma and that same year, Brown and Feinberg noted that between 1 and $20 \%$ of patients with asthma have positive skin tests to aspergillus extract [4]. The first report of allergic bronchopulmonary aspergillosis (ABPA) was proposed by Hinson et al in 3 patients in 1952, all of whom were asthmatics presenting with persistent wheeze, sputum production, fever, eosinophilia and pulmonary infiltrates. ABPA can be caused by a variety of aspergillus species, most commonly A. fumigatus but other species have been implicated including $A$. niger, A. flavus, A. nidulans, A. oryzae, and A. terreus [5].

Aspergillus is a saprophytic mold and its natural habitat is the soil [5]. It is found worldwide indoors and outdoors in potted soil, compost, freshly cut grasses, decaying vegetation and in sewers. Aspergillus produces a bountiful number of spores and releases $2-3$ micron sized spores into the air daily [6]. It grows best at $37-40{ }^{\circ} \mathrm{C}$, which is similar to the temperature in the lungs. These spores will remain airborne for a long period of time. It is estimated that humans inhale hundreds of spores daily.

Several fungi other than aspergillus have been known to be implicated. Hence, the term allergic bronchopulmonary mycoses (ABPM) would be more appropriate unless the specific fungus is identified which could be candida, helminthosporium, curvularia, bipolaris, cladosporium, or others. In this review article, we will focus on the prototype allergic bronchopulmonary aspergillosis (ABPA).

\section{EPIDEMIOLOGY}

The exact prevalence of ABPA is unknown. It depends on a variety of factors including the severity of asthma, presence of immediate hypersensitivity to aspergillus, method of detection, and the diagnostic criteria used. It is estimated to affect about $2 \%$ of asthmatics and $1-15 \%$ of cystic fibrosis patients [7], without gender predilection. Typically, it affects asthma patients in their third or fourth decade [8].

\section{PATHOGENESIS}

Based mainly on in vitro studies, multiple theories have been proposed regarding the pathogenesis of ABPA.

The most common theory suggests that in patients with asthma and cystic fibrosis who are genetically predisposed and have increased pulmonary mucus viscosity, the inhalation of aspergillus spores causes colonization and deposition of the hyphae [9]. These hyphae release antigens which are disruptive to the epithelial barriers impeding mucociliary clearance. This results in the attraction of inflammatory cells that in turn release cytokines causing inflammation. The process is hypothesized to have a Th2 cell predominance over Th1 cell causing a release of IL-4, IL-5, and IL-13, resulting in eosinophilia and elevation of IgE [10]. The influx of these inflammatory cells is directly involved in tissue destruction. In the lungs, this can cause central bronchiectasis.

A second hypothesis is based on the findings of a study by Garcia et al who reported a different pattern of cellular responses in individuals with ABPA than those with only allergic asthma [11]. They observed a downregulation of chemokine receptors CCR 4 and CXCR3 in vitro by allergen specific CD4+ T cells of ABPA patients, which is opposite to the effect in patients with only allergic asthma.

A third hypothesis is by Miller et al for cystic fibrosis patients suggesting that the cystic fibrosis transmembrane conductance regulator (CFTR) gene has a greater chance of mutating compared to healthy controls [12].

The pathogenesis of ABPA is attributed to mucoid impaction of the bronchi with fungal hyphae, eosinophilic pneumonia or bronchitis, and bronchocentric granulomatosis with tissue eosinophilia [13]. In the airways, septated hyphae with acute dichotomous branching is seen in the lumen without invasion of the mucosa. Aspergillus is found in sputum cultures in two thirds of patients although often is 
not seen by microscopy. Key findings in sputum are Curschmann spirals (mucus plugs) and eosinophilic debris (Charcot-Leyden crystals) [14].

\section{DIAGNOSIS AND EVALUATION}

The diagnosis of ABPA should be based on clinical suspicion and supported by radiologic and laboratory findings. An important clinical feature of the presentation of ABPA is deterioration of pulmonary symptoms with increased wheezing and shortness of breath. These patients typically present with fever, malaise, productive cough with brownish mucus plugs, and occasionally hemoptysis [15].

The diagnosis is typically suspected in patients with recurrent asthma or cystic fibrosis exacerbations. It is important to rule out other causes before committing to the diagnosis of ABPA. Other causes of bronchiectasis could be post infection, immunodeficiency, or ciliary dysfunction. Several other causes of eosinophilia should also be considered such as eosinophilic pneumonia, eosinophilic granulomatosis with polyangiitis, hyper eosinophilic synd- rome, hypersensitivity reactions, and parasitic infections.

In general, the evaluation should consist of obtaining a complete blood count, skin prick test to aspergillus, specific IgE to aspergillus, serum precipitins (or IgG antibody) to aspergillus, chest x-ray, and a high resolution computed tomography (HRCT) of the lungs [16]. If the skin prick test is negative, intradermal testing can be considered. In general, specific IgE to aspergillus alone suggests sensitization only which is not diagnostic of ABPA and is frequently present in patients with severe eosinophilic asthma. Total serum IgE should be obtained as this is useful during monitoring.

ABPA (or ABPM) should be considered among the cases of poorly controlled asthma or cystic fibrosis. Currently, the most widely accepted criteria are those proposed by Rosenberg and Patterson [17]. In patients with asthma, the severity of their condition does not determine diagnosis. If most of the criteria presented in table 1 are met, there is a high clinical suspicion of ABPA [18].

Таблица 1 / Table 1

Diagnostic criteria for ABPA in asthmatics /

Диагностические критерии аллергического бронхолегочного аспергиллеза (АБЛА) у пациентов с астмой

\begin{tabular}{|c|c|}
\hline Major Criteria / Основные критерии & Minor Criteria / Второстепенные критерии \\
\hline Chronic asthma / Хроническая астма & $\begin{array}{l}\text { Golden brown mucus sputum production / } \\
\text { Золотисто-коричневая слизь }\end{array}$ \\
\hline $\begin{array}{l}\text { Transient pulmonary infiltrates (fleeting) / Преходящие легочные } \\
\text { инфильтраты (мимолетные) }\end{array}$ & $\begin{array}{l}\text { Sputum positive for Aspergillus / } \\
\text { Мокрота, положительная на Aspergillus }\end{array}$ \\
\hline $\begin{array}{l}\text { Immediate cutaneous hypersensitivity to aspergillus species/ } \\
\text { Немедленная кожная гиперчувствительность к видам аспергилл }\end{array}$ & $\begin{array}{l}\text { Late skin reactivity to aspergillus species / } \\
\text { Поздняя кожная реактивность на виды аспергилл }\end{array}$ \\
\hline $\begin{array}{l}\text { Elevated total serum IgE > } 1000 \text { ng/mL (417 IU/mL) / } \\
\text { Повышенный общий сывороточный IgE > } 1000 \text { нг/Мл (417 ME/мл) }\end{array}$ & \\
\hline Blood eosinophilia / Эозинофилия & \\
\hline $\begin{array}{l}\text { Elevated serum specific IgG and IgE to Aspergillus / } \\
\text { Повышенные сывороточные специфические IgG и IgE к Aspergillus }\end{array}$ & \\
\hline $\begin{array}{l}\text { Central/proximal bronchiectasis / } \\
\text { Центральный/проксимальный бронхоэктаз }\end{array}$ & \\
\hline
\end{tabular}

Adapted from Rosenberg and Patterson [18].

Those criteria were later revised by Greenberger who reported that only asthma, immediate skin hypersensitivity to aspergillus, total serum $\mathrm{IgE}$ $>1000 \mathrm{ng} / \mathrm{mL}(>417 \mathrm{IU} / \mathrm{mL})$ and central bronchiectasis in the absence of distal bronchiectasis is required for the diagnosis [19]. Since central bronchiectasis is not required for diagnosis, some suggested that patients can be categorized into subgroups: ABPA-Seropositive and ABPA-Central bronchiectasis [20]. Agarwal and coworkers proposed that 
all patients diagnosed with asthma must be screened for specific IgE levels to aspergillus [21]. If negative, total IgE levels and sensitization to other fungi should be obtained to rule out ABPM. In patients sensitized to aspergillus, total IgE levels below $1000 \mathrm{IU} / \mathrm{mL}$ and uncontrolled asthma suggest severe asthma with fungal sensitization as an alternative to ABPA. This subset of patients may benefit from anti-fungal therapy. In patients with fungal sensitization to aspergillus and a total $\mathrm{IgE}$ level greater than $1000 \mathrm{IU} / \mathrm{mL}$, clinicians should obtain eosinophil levels, immediate skin hypersensitivity, and specific IgG to aspergillus. If any two of the criteria are positive, ABPA is confirmed and HRCT should be performed for staging of the disease. Although some authors suggest a significantly higher total serum IgE level of $1000 \mathrm{IU} / \mathrm{mL}$ (2400 ng/mL) for diagnosis [22], most authors follow the $1000 \mathrm{ng} / \mathrm{mL}(417 \mathrm{IU} / \mathrm{mL})$ as a cutoff level. Table 2 shows the diagnostic criteria of ABPA in patients with cystic fibrosis [17].

Testing for IgG antibodies to aspergillus species (or other suspected molds) is performed by ELISA assay which replaced testing for precipitins by gel immunodiffusion [6]. Pulmonary function testing is valuable in monitoring the disease severity but not for the diagnosis of ABPA [17]. Spirometry typically shows an obstructive pattern but can also develop restriction in late stages of the disease. After treatment with corticosteroids or during remission, a normalization of these parameters often occur.

\section{RADIOLOGIC FEATURES AND STAGING}

Chest $\mathrm{x}$-ray and often HRCT are recommended during evaluating patients for ABPA. Chest x-ray can show transient changes such as fleeting patchy areas of consolidation 17]. The infiltrates can appear as gloved finger shadows due to mucoid impaction in dilated bronchi. It can also present as a lobar or segmental atelectasis. When permanent changes occur, parallel-line shadows representing bronchial widening and ring shadows approximately $1-2 \mathrm{~cm}$ in diameter may be visualized. Additionally, it can be accompanied by pulmonary fibrosis.

High resolution chest tomography can reveal a variety of parenchymal findings including central bronchiectasis, consolidation, centrilobular nodules with tree-in-bud opacities, bronchial wall thickening, mosaic attenuation, and areas of atelectasis [23]. A characteristic finding of ABPA is bronchiectasis of greater than two lobes at lobar and segmental levels in a majority of the airways [14].

Based on radiologic features, criteria have been incorporated in classifying the stages of ABPA (Table 3). Five stages have been described: acute, remission, exacerbation, corticosteroid-dependent asthma, and fibrotic [24].

Criteria for ABPA in cystic fibrosis patients /

Критерии аллергического бронхолегочного аспергиллеза у пациентов с муковисцидозом

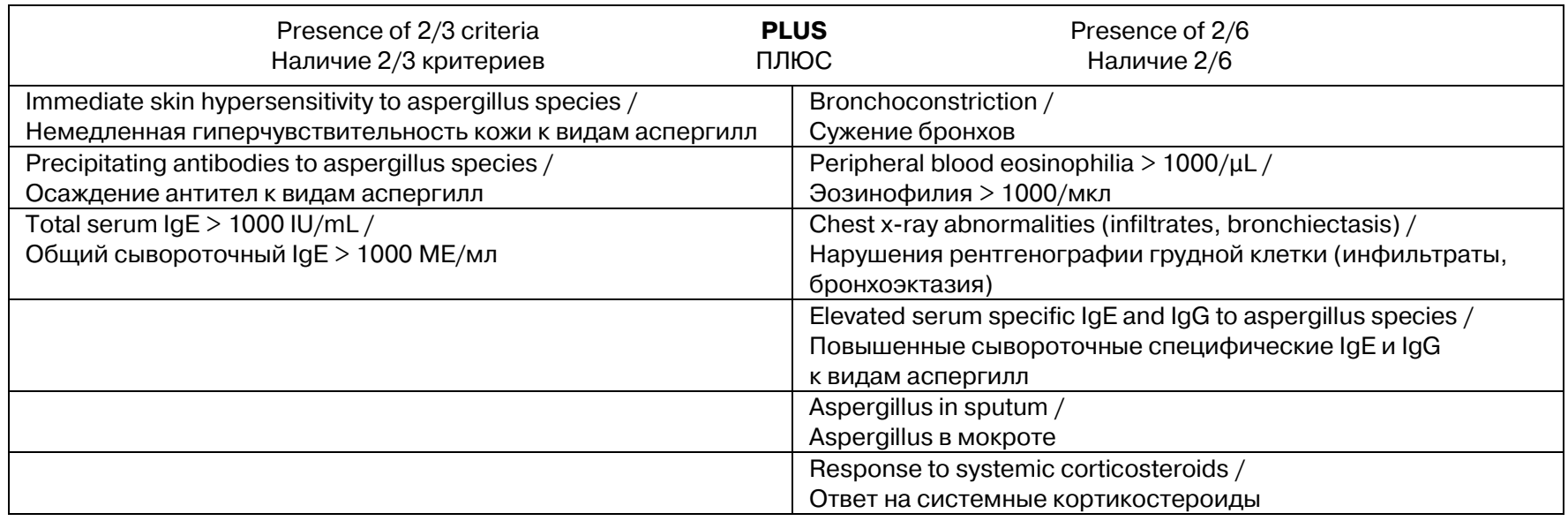

Modified from Shah and Panjabi [17]. 
Staging of ABPA /

Стадии аллергического бронхолегочного аспергиллеза

\begin{tabular}{|c|c|}
\hline $\begin{array}{l}\text { Stage I: Acute / } \\
\text { Стадия I: острая }\end{array}$ & $\begin{array}{l}\text { Normal radiographic features or pulmonary infiltrate with mucoid impaction especially } \\
\text { in the upper lobes / Нормальные рентгенологические признаки или легочный } \\
\text { инфильтрат со слизистой оболочкой, особенно в верхних долях }\end{array}$ \\
\hline $\begin{array}{l}\text { Stage II: Remission / } \\
\text { Стадия II: Ремиссия }\end{array}$ & $\begin{array}{l}\text { Radiologic infiltrate clear / Радиологический инфильтрат очищает } \\
\text { - Decreased in total serum IgE and eosinophilia / Снижение общего сывороточного } \\
\text { IgE и эозинофилии } \\
\text { - Prednisone tapered and goal to discontinue / Преднизалон отменяется }\end{array}$ \\
\hline $\begin{array}{l}\text { Stage III: Exacerbation / } \\
\text { Стадия III: обострение }\end{array}$ & $\begin{array}{l}\text { Reappearance of infiltrates and mucoid impaction in previously cleared areas } \\
\text { or in new ones / Повторное появление инфильтратов и слизистой оболочки } \\
\text { в ранее очищенных или новых участках } \\
\text { Restart treatment with prednisone / Возобновить лечение преднизалоном }\end{array}$ \\
\hline $\begin{array}{l}\text { Stage IV: Corticosteroid-dependent asthma / } \\
\text { Стадия IV: кортикостероид-зависимая астма }\end{array}$ & $\begin{array}{l}\text { Glucocorticoid-dependent with return of symptoms if tapering or discontinuation is } \\
\text { attempted / Зависимость от глюкокортикоидов с возвращением симптомов } \\
\text { при попытке снижения дозировки или отмены } \\
\text { Normal chest radiography or fixed pulmonary орасities are visualized / Нормальная } \\
\text { рентгенография грудной клетки или фиксированные легочные помутнения }\end{array}$ \\
\hline
\end{tabular}

Modified from Greenberger and Patterson [24].

Patients can initially present at any stage. Although the common age for ABPA is young and middle-aged adults, children are not exempt, as illustrated in the following case.

\section{CASE PRESENTATION}

One of our patients was a 12-year-old female with a history of eczema and persistent asthma since early childhood. At 8 years of age, she had a severe asthma exacerbation that required admission to the intensive care unit for impending respiratory failure. Since 10 years of age, in spite of adequate routine asthma therapy, she had many exacerbations requiring frequent emergency treatment and five hospitalizations. There were no apparent triggers of the exacerbations. She was on combined fluticasone / salmeterol $230 \mathrm{mcg} / 21 \mathrm{mcg} 2$ puffs twice daily, loratadine $10 \mathrm{mg}$ in the morning and montelukast $10 \mathrm{mg}$ at bedtime. However, she experienced a worsening of her asthma and a decline of her flow function on spirometry despite strict adherence to medications. She had persistent wheezing that required the intake of albuterol inhaler 3-4 times daily. She also received prednisone courses numerous times, including more than ten times during the past year, with improvement for short durations. During the recent hospitalization, the Allergy/Immunology service was consulted. Her CBC was within normal limits, including absolute eosinophil count $(100 / \mu \mathrm{L})$ but the test was done while she was on systemic corticosteroid administration. Her serum total $\mathrm{IgE}$ level was $2040 \mathrm{IU} / \mathrm{mL}$ raising suspicion of ABPA. Serum specific antibodies to aspergillus were elevated for both $\operatorname{IgE}(28.5 \mathrm{IU} / \mathrm{mL})$ and $\mathrm{IgG}(23.7 \mathrm{IU} / \mathrm{mL})$. Chest $\mathrm{X}$-ray showed bilateral hyperinflation, streaky atelectasis in the right middle lobe, and peribronchial cuffing. HRCT of the lungs did not show any infiltrates or bronchiectasis. She did meet the majority of ABPA criteria and was treated with $40 \mathrm{mg}$ prednisone daily until follow up in the clinic. At follow up after two weeks, she reported marked improvement in her asthma symptoms, but continued to experience nocturnal chest tightness and coughing. Her spirometry revealed a FEV1 1.23 L (53\%), FVC $2.10 \mathrm{~L}(81 \%)$, FEV1/FVC 59\%, and FEF $25-75 \%$ $0.56 \mathrm{~L} / \mathrm{s}(18 \%)$. Her IgE level dropped to $1350 \mathrm{IU} / \mathrm{mL}$. Her eosinophil count was very low due to prednisone intake. The prednisone dose was reduced to $40 \mathrm{mg}$ every other day (EOD) and beclomethasone dipropionate 1 puff twice a day was added to her regimen to improve small airway inflammation. After one month, she reported dramatic improvement in her symptoms and minimal nocturnal symptoms. Repeat spirometry showed a FEV1 1.95 L (81\%), 
FVC 2.45 L (92\%), FEV1/FVC 80\%, FEF 25-75\% $1.80 \mathrm{~L} / \mathrm{s}(51 \%)$. Her IgE level remained relatively stable at $1410 \mathrm{IU} / \mathrm{mL}$. Due to subjective and objective improvement, her prednisone was decreased to $30 \mathrm{mg}$ EOD until follow-up in two weeks. The drop of her initial $\mathrm{IgE}$ level from $2040 \mathrm{IU} / \mathrm{mL}$ to $1220 \mathrm{IU} / \mathrm{mL}$ after four months was associated with improvement in her FEV1 from 59\% predicted to $81 \%$ predicted. She will continue regular follow up in the clinic and gradually reduce the prednisone dose according to her clinical course.

\section{TREATMENT}

The primary goals of treatment are to prevent the development or progression of bronchiectasis, preserve lung function, and improve pulmonary physiology. In general, inhaled corticosteroids are ineffective in preventing acute ABPA episodes [15]. Oral corticosteroids are the mainstay of therapy [25]. It is recommended to complete a minimal of three months of treatment starting with prednisone $0.5 \mathrm{mg} / \mathrm{kg} /$ day for two weeks, then alternate days for three months followed by staging of the disease. Some experts start at a higher dose at $0.75 \mathrm{mg} / \mathrm{kg} / \mathrm{day}$ for 6 weeks, followed by $0.5 \mathrm{mg} / \mathrm{kg} /$ day for 6 weeks, and eventually taper over a period of 6-12 months to prevent disease recurrence [26]. There are no studies comparing regimens at this time, although most experts tend to favor longer therapy with higher dosages of prednisone [27]. Monitoring of total serum IgE level monthly is important in determining duration of treatment as well as in predicting pending relapse. In general, aiming for 35\% reduction in $\operatorname{IgE}$ is suggestive of a good response and decreases the likelihood of relapse. It is important to consider the patient's clinical response, as occasionally the level of $\operatorname{IgE}$ does not drop by $35 \%$ when the initial total $\mathrm{IgE}$ is less than $2500 \mathrm{IU} / \mathrm{mL}$ [28].

In patients with corticosteroid-dependent ABPA, Stevens and coworkers reported clinical improvement with the use of $200 \mathrm{mg}$ of itraconazole twice a day [29]. Liver function should be monitored regularly, and treatment is typically for three to six months although this varies depending on the re- sponse [30]. The mechanism of action is thought to be due to a decrease in antigenic stimulus that causes inflammation in the bronchi [31]. Another proposed hypothesis is that it causes increased levels of serum corticosteroids by interfering with the metabolism. A major concern is that adrenal suppression has been observed with concomitant use of corticosteroids and itraconazole [32]. Voriconazole and posaconazole have also been used and has improved tolerance and bioavailability [33], but there are no studies that showed superiority over itraconazole.

Anti-IgE (omalizumab) therapy using doses recommended for asthma, showed promising results with improvement in respiratory symptoms in patients with ABPA [34]. In one study, sixteen adult asthmatic ABPA patients were treated with omalizumab for one year and had clinical improvement with fewer asthma exacerbations and requiring lower doses of corticosteroids. Currently, omalizumab is based on weight and total serum $\operatorname{IgE}$ and majority of patients exceed the recommended dose range due to grossly elevated $\operatorname{IgE}[14]$. Based on available data, it remains a second line option for patients with ABPA.

Immunotherapy with aspergillus or other fungi have not been fully evaluated and is currently not recommended for treatment [35]. Patients who are on immunotherapy for allergic rhinitis can continue treatment safely.

\section{CONCLUSION}

ABPA should be considered in patients with poorly controlled asthma despite appropriate routine therapy and environmental control. The need for frequent courses of corticosteroids with temporary improvement should raise the index of suspicion and appropriate evaluation be done. Early recognition and prompt initiation of appropriate corticosteroid treatment regimen would reduce the risk of development or progression of bronchiectasis and lung tissue damage [36]. Regular follow up and monitoring serum total IgE level can predict exacerbations and should prompt corticosteroid treatment. Long term follow-up is important as relapses can occur years of remission. 


\section{REFERENCES}

1. Centers for Disease Control and Prevention. Etymologia: Aspergillus. Emerg Infect Dis. 2006;12(3):415.

2. Lee J. Discovery of Aspergillus as a Human Pathogen. Retrieved January 15, 2019, from http://www.antimicrobe.org/ hisphoto/history/Aspergillus-Human\%20Pathogens.asp.

3. Macartney JN. Pulmonary Aspergillosis: A Review and a Description of Three New Cases. Thorax. 1964;19(4): 287-297.

4. Hinson KF, Moon AJ, Plummer NS. Broncho-pulmonary aspergillosis; a review and a report of eight new cases. Thorax. 1952;7(4):317-333.

5. Latgé JP. Aspergillus fumigatus and Aspergillosis. Clin Microbiol Rev. 1999; 12(2):310-350.

6. Knutsen AP, Slavin RG. Allergic bronchopulmonary aspergillosis in asthma and cystic fibrosis. Clin Dev Immunol. 2011;2011:843763:1-13.

7. Patterson K, Strek ME. Allergic Bronchopulmonary Aspergillosis. Proc Am Thorac Soc. 2010;7(3):237- 44.

8. Tillie-Leblond I, Tonnel AB. Allergic bronchopulmonary aspergillosis. Allergy. 2005;60(8):1004-1013.

9. Amitani R, Kawanami R. Interaction of Aspergillus with human respiratory mucosa: a study with organ culture model. Med Mycol. 2009;47 Suppl 1:S127-131.

10. Kauffman HF, Tomee JF, van der Werf TS, de Monchy JG, Koeter GK. Review of fungus-induced asthmatic reactions. Am J Respir Crit Care Med. 1995;151(6): 2109-2116.

11. Garcia G, Humbert M, Capel F, et al. Chemokine receptor expression on allergen-specific $\mathrm{T}$ cells in asthma and allergic bronchopulmonary aspergillosis. Allergy. 2007; 62(2): $170-177$.

12. Miller PW, Hamosh A, Macek M, Jr., et al. Cystic fibrosis transmembrane conductance regulator (CFTR) gene mutations in allergic bronchopulmonary aspergillosis. Am J Hum Genet. 1996;59(1):45-51.

13. Ueki S, Hebisawa A, Kitani M, Asano K, Neves JS. Allergic Bronchopulmonary Aspergillosis-A Luminal Hypereosinophilic Disease With Extracellular Trap Cell Death. Front Immunol. 2018;9(2346):1-9.

14. Douglass JA, Sandrini A, Holgate ST, O'Hehir RE. (2013). Allergic Bronchopulmonary Aspergillosis and Hypersensitivity Pneumonitis. In: N. Adkinson Jr, B. Bochner, A. Burks, W. Busse, S. Holgate, R. Lemanske, R. O'Hehir (Eds.), Middleton's Allergy Principles and Practice $8^{\text {th }}$ edition: 2-Volume Set. (pp1000-1012). Philadelphia, PA: Elsevier Saunders.

15. Akuthota P, Weller P. (2017, June 29). Clinical manifestations and diagnosis of allergic bronchopulmonary aspergillosis - UpToDate. Retrieved January 15, 2019, from https://www.uptodate.com/contents/clinical-manifestationsand-diagnosis-of-allergic-bronchopulmonary-aspergillosis? search $=$ abpa\&source $=$ search result\&selectedTitle $=1 \sim 51$ \&usage type $=$ default\&display_rank=1\#H1248738776.
16. Agarwal R, Maskey D, Aggarwal AN, et al. Diagnostic Performance of Various Tests and Criteria Employed in Allergic Bronchopulmonary Aspergillosis: A Latent Class Analysis. PLoS One. 2013;8(4)e61105:1-7.

17. Shah A, Panjabi C. Allergic Bronchopulmonary Aspergillosis: A Perplexing Clinical Entity. Allergy Asthma Immunol Res. 2016;8(4):282-297.

18. Rosenberg M, Patterson R, Mintzer R, Cooper BJ, Roberts M, Harris KE. Clinical and immunologic criteria for the diagnosis of allergic bronchopulmonary aspergillosis. Ann Intern Med. 1977;86(4):405-414.

19. Greenberger PA. Allergic bronchopulmonary aspergillosis. J Allergy Clin Immunol. 2002;110(5):685-692.

20. Agarwal R, Khan A, Gupta D, Aggarwal AN, Saxena AK, Chakrabarti A. An alternate method of classifying allergic bronchopulmonary aspergillosis based on high-attenuation mucus. PLoS One. 2010;5(12):e15346:1-9.

21. Agarwal R, Chakrabarti A, Shah A, et al. Allergic bronchopulmonary aspergillosis: review of literature and proposal of new diagnostic and classification criteria. Clin Exp Allergy. 2013;43(8):850-873.

22. Agarwal R, Aggarwal AN, Gupta D, Jindal SK. Aspergillus hypersensitivity and allergic bronchopulmonary aspergillosis in patients with bronchial asthma: systematic review and meta-analysis. Int J Tuberc Lung Dis. 2009; 13(8):936-944.

23. Menzies D, Holmes L, McCumesky G, Prys-Picard C, Niven R. Aspergillus sensitization is associated with airflow limitation and bronchiectasis in severe asthma. Allergy. 2011;66(5):679-685.

24. Greenberger PA, Patterson R. Allergic bronchopulmonary aspergillosis. Model of bronchopulmonary disease with defined serologic, radiologic, pathologic and clinical findings from asthma to fatal destructive lung disease. Chest. 1987;91(6 Suppl):165s-171s.

25. Patterson R, Greenberger PA, Halwig JM, Liotta JL, Roberts M. Allergic bronchopulmonary aspergillosis. Natural history and classification of early disease by serologic and roentgenographic studies. Arch Intern Med. 1986;146(5):916-918.

26. Agarwal R, Gupta D, Aggarwal AN, Behera D, Jindal SK. Allergic bronchopulmonary aspergillosis: lessons from 126 patients attending a chest clinic in north India. Chest. 2006;130(2):442 - 448 .

27. Limper AH, Knox KS, Sarosi GA, et al. An official American Thoracic Society statement: Treatment of fungal infections in adult pulmonary and critical care patients. Am J Respir Crit Care Med. 2011;183(1):96-128.

28. Agarwal R, Gupta D, Aggarwal AN, et al. Clinical significance of decline in serum IgE levels in allergic bronchopulmonary aspergillosis. Respir Med. 2010;104(2):204 210.

29. Stevens DA, Schwartz HJ, Lee JY, et al. A randomized trial of itraconazole in allergic bronchopulmonary aspergillosis. N Engl J Med. 2000;342(11):756-762. 
30. Stevens DA, Moss RB, Kurup VP, et al. Allergic bronchopulmonary aspergillosis in cystic fibrosis-state of the art: Cystic Fibrosis Foundation Consensus Conference. Clin Infect Dis. 2003;37(Suppl 3):S225-264.

31. Patterson TF, Thompson GR, 3rd, Denning DW, et al. Practice Guidelines for the Diagnosis and Management of Aspergillosis: 2016 Update by the Infectious Diseases Society of America. Clin Infect Dis. 2016;63(4):e1- e60.

32. Parmar JS, Howell T, Kelly J, Bilton D. Profound adrenal suppression secondary to treatment with low dose inhaled steroids and itraconazole in allergic bronchopulmonary aspergillosis in cystic fibrosis. Thorax. 2002;57(8):749-750.
33. Chishimba L, Niven RM, Cooley J, Denning DW. Voriconazole and posaconazole improve asthma severity in allergic bronchopulmonary aspergillosis and severe asthma with fungal sensitization. J Asthma. 2012;49(4):423 - 433.

34. Tillie-Leblond I, Germaud P, Leroyer C, et al. Allergic bronchopulmonary aspergillosis and omalizumab. Allergy. 2011;66(9):1254-1256.

35. Knutsen AP, Bush RK, Demain JG, et al. Fungi and allergic lower respiratory tract diseases. $J$ Allergy Clin Immunol. 2012;129(2):280-291.

36. Tracy MC, Okorie CUA, Foley EA, Moss RB. Allergic Bronchopulmonary Aspergillosis. J Fungi (Basel). 2016; 2(2) 17:1-18.

(C) Rashmi D’Mello, Sasikumar Kilaikode, Sami L. Bahna, 2019 This work is licensed under a Creative Commons Attribution 4.0 International License

Received 16.02.2019

Accepted 14.03.2018

DOI: 10.22363/2313-0245-2019-23-1-62-69

\section{АЛЛЕРГИЧЕСКИЙ БРОНХОЛЕГОЧНЫЙ АСПЕРГИЛЛЕЗ Рашми д'Мелло ${ }^{1}$, Сасикумар Килайкод ${ }^{2}$, Сами Л. Бахна ${ }^{1}$ \\ ${ }^{1}$ Allergy and Immunology Section, Louisiana State University Health Sciences Center, Shreveport, Louisiana, U.S.A. \\ ${ }^{2}$ Pediatric Pulmonary Section, Louisiana State University Health Sciences Center, Shreveport, Louisiana, U.S.A.}

Aspergillus является сапрофитной плесенью, его естественной средой обитания является почва. Он встречается по всему миру в помещениях и на открытом воздухе, в почве домашних растений, компосте, свежескошенных травах, гниющей растительности и в канализации. Aspergillus производит большое количество спор и выпускает споры размером 2-3 микрона в воздух ежедневно. Лучше всего растет при $37-40{ }^{\circ} \mathrm{C}$, что соответствует температуре в легких. Эти споры остаются в воздухе в течение длительного периода времени. Подсчитано, что люди ежедневно вдыхают сотни спор. Известно, что заболевания вызывают не только Aspergillus, но и другие грибы. Следовательно, термин «аллергические бронхолегочные микозы» был бы более уместным, пока не идентифицирован конкретный гриб, который может быть кандидой, гельминтоспорием, куркулярией, биполирисом, кладоспорием или другими. Обзорная статья посвящена прототипу аллергического бронхолегочного аспергиллеза, его эпидемиологии, патогенезу, диагностике и лечению. Бронхолегочный аспергиллез возможен у пациентов с плохо контролируемой астмой, несмотря на соответствующую рутинную терапию и контроль окружающей среды. Раннее распознавание и своевременное начало соответствующей схемы лечения кортикостероидами уменьшит риск развития или прогрессирования бронхоэктазов и повреждения тканей легких. Регулярное наблюдение и мониторинг общего уровня IgE в сыворотке могут предсказать обострения и должны сопровождать терапию кортикостероидами. Важно долгосрочное наблюдение, поскольку рецидивы могут произойти через годы ремиссии.

Ключевые слова: аллергический бронхолегочный аспергиллез, аллергический легочный микоз, неконтролируемая астма, астма, муковисцидоз, бронхоэктаз, аспергиллез

Автор-корреспондент: Сами Л. Бахна, доктор медицинских наук, руководитель секции аллергии и иммунологии Медицинского центр Университета штата Луизиана, Шривпорт, Луизиана 71130-3239, США

E-mail: SBahna@LSUHSC.edu

() Рашми д'Мелло, Сасикумар Килайкод, Сами Л. Бахна, 2019 This work is licensed under a Creative Commons Attribution 4.0 International License

Поступила 16.02.2019

Принята 14.03.2018 